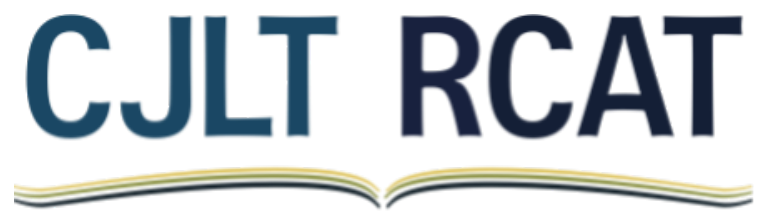

Canadian Journal of Learning and Technology

La Revue canadienne de l'apprentissage et de la technologie

Volume $47(1)$

Winter / Hiver 2021

\title{
Pedagogical Design: Bridging Learning Theory and Learning Analytics
}

\section{Conception pédagogique : Rapprocher la théorie de l'apprentissage et l'analyse de l'apprentissage}

Seyyed Kazem Banihashem, Wageningen University \& Research, The Netherlands

Leah P. Macfadyen, University of British Columbia, Canada

\begin{abstract}
Which learning analytics (LA) approach might be the best choice for your teaching and learning context? Learning analytics as a field of research and application seeks to collect, analyze, report, and interpret educational data with the goal of improving teaching and learning. However, hasty adoption of learning analytics tools and methods that are simply convenient, promoted, or available risks allowing learning analytics to "drive the pedagogical bus." In this paper, we propose that careful reflection on pedagogical design choices and the learning theory that underpins them can and should inform selection of relevant learning analytics tools and approaches. We broadly review established learning theories and the implications of each for pedagogical design; for each design approach, we offer examples of learning analytics most clearly aligned with the theoretical perspectives on learning and knowledge that have shaped it. Moreover, we argue that careful consideration of the learning theory underpinning the pragmatics of pedagogical design choices should guide LA implementation, and help educators and designers avoid the risk of gathering data on, and measuring outcomes for, activities that are not relevant to their pedagogical design or goals.
\end{abstract}

Keywords: Epistemology; learning analytics; learning theory; pedagogical design; learning design; instructional design; learning ecosystem design

\section{Résumé}

Quelle approche de l'analyse de l'apprentissage pourrait être le meilleur choix pour votre contexte d'enseignement et d'apprentissage ? L'analyse de l'apprentissage, en tant que domaine de recherche et d'application, cherche à collecter, analyser, rapporter et interpréter les données éducatives dans le but d'améliorer l'enseignement et l'apprentissage. Cependant, l'adoption précipitée d'outils et de méthodes d'analyse de l'apprentissage qui sont simplement pratiques, promus ou disponibles risque de 
permettre à l'analyse de l'apprentissage de "conduire le bus pédagogique". Dans cet article, nous proposons qu'une réflexion approfondie sur les choix de conception pédagogique et la théorie de l'apprentissage qui les sous-tend puisse et doive éclairer la sélection d'outils et d'approches d'analyse de l'apprentissage pertinents. Nous examinons de manière générale les théories de l'apprentissage établies et les implications de chacune d'entre elles pour la conception pédagogique ; pour chaque approche de conception, nous proposons des exemples d'analyse de l'apprentissage les plus clairement alignés avec les perspectives théoriques sur l'apprentissage et la connaissance qui l'ont façonnée. En outre, nous soutenons qu'un examen attentif de la théorie de l'apprentissage qui sous-tend la pragmatique des choix de conception pédagogique devrait guider la mise en œuvre des analyses de l'apprentissage et aider les éducateurs et les concepteurs à éviter le risque de recueillir des données sur des activités qui ne sont pas pertinentes pour leur conception ou leurs objectifs pédagogiques, et de mesurer les résultats de ces activités.

Mots-clés : Épistémologie ; analyse de l'apprentissage ; théorie de l'apprentissage ; conception pédagogique ; conception de l'apprentissage ; conception pédagogique ; conception de l'écosystème d'apprentissage

\section{Introduction}

Internet technologies and digital tools have allowed innovative educators to experiment with new approaches to facilitating learning and empowering learners. Investigators report, for instance, that digital technologies can facilitate learner engagement (Chen et al., 2010), empower learning (Prasertsilp, 2013) or assist students with disabilities (Perelmutter et al., 2017; Stauter et al., 2019). Technology-enhanced learning is now a core organizing framework in education, allowing learners with an Internet connection to learn anytime and from anywhere. Moreover, in online learning environments, every action generates data which can be collected, stored, and analyzed in pursuit of new understandings of learner behaviours and learning (Clow, 2013). As investigators began to realize the value of these critical insights for teaching and learning, the new field of learning analytics (LA) emerged: the collection, measurement, analysis, and reporting of data about learners and their learning contexts, with the goal of understanding and optimizing learning (Long \& Siemens, 2011). As an interdisciplinary field of study, LA has borrowed concepts, methods, and ideas from statistics, machine learning, business intelligence, educational psychology, learning sciences, and computer science (Banihashem et al., 2018). As with many new fields of study, however, a gap remains between theory and practice (Stewart, 2017), or, one might argue, between research findings reported in the LA literature, and meaningful educational implementations.

In this paper, we seek to alert educators and designers to the risk of LA-related technological determinism, which can occur when LA tools and methods are implemented without consideration of theoretical foundations, underlying perspectives on learning or achievement, or the particular learning goals of a given pedagogical design. To do so, we explore the theoretical foundations of different 
approaches to and uses of learning analytics, with a particular focus on the concept of learning, as envisioned by different learning theories and manifested in different approaches to pedagogical design.

\section{Learning Analytics and Learning Theory}

Learning analytics is focussed on learning (Gašević et al., 2015). It can provide insights into learners and learning processes, and help instructors make design and teaching decisions based on evidence (Banihashem et al., 2018). Different fields of study conceive of learning differently, and although scholars from diverse disciplines, such as cognitive science, computer science, educational psychology, applied linguistics, and anthropology, have contributed to our understanding of learning (Sawyer, 2014), it remains a complex and contested concept (Barron et al., 2015). Nonetheless, educators, and even institutional administrators, need a clear understanding of what they mean by learning, if they hope to meaningfully specify learning outcomes or assess learner achievement. Similarly, designers and others involved in selecting and implementing learning analytics options need a clear understanding of learning (and what constitutes achievement), so that they can make informed decisions about what kind of data they need to collect and analyze to be able to predict or monitor progress towards desired learning goals.

In the field of education, learning theories seek to explain how and why learning is happening -how learners absorb, process, and retain knowledge during learning -- and illuminate perceptions of learning as a process or product (Bell, 2011; Smith, 1999-2020). Banihashem et al. 2019 collected and analyzed LA expert perspectives on the relationship between learning theories and learning analytics, and reported their belief that consideration of learning theories can support effective implementation and use of learning analytics in three important ways:

- Learning theory can underpin design and selection of appropriate learning analytics tools or approaches.

- Learning theory can guide learning analytics use, by clarifying assumptions about what learning mean, how individuals learn, how learners process information, and which factors are important in the teaching and learning process.

- Learning theory can assist with sense-making of data, because it can explain learning, behaviour, experiences, and outcomes.

In other words, consideration of learning theories can help educators plan how and where to make best use of learning analytics in educational contexts, decide which types of data need to be collected, and make appropriate decisions about how data should be represented and reported. Importantly, learning theory can help us to translate data into knowledge, guiding our interpretations of data that may point to effective interventions. Clarifying our conception of learning in each context demands that we clearly understand the learning theory that underpins teaching and learning in that context. 


\section{Design for Learning: Connecting Learning Analytics with Learning Theory}

Learning theories play a foundational role in different approaches to designing for teaching and learning. Unsurprisingly, different learning theories dictate different approaches. Each offers its own prescription for a pedagogical frameworks that can shape how teaching and learning happen in a given context, specifying resources, teaching guidelines, and learning values that are designed to provide productive teaching and facilitate learning (Halttunen, 2011; Romiszowski, 2016). Below, we review the best-known learning theories and the approaches to design for learning that have emerged from each perspective. For each, we then offer examples of LA applications or approaches that may meaningfully offer insight into learning as understood within that design framework.

\section{Instructional Design, Objectivist Learning Theories, and Behaviourist Learning Analytics}

The field of instructional design (also called instructional systems design) has largely been shaped by behaviourist and cognitivist perspectives on learning. While behaviourism and cognitivism differ in their understanding of how learners perceive the world, they share an objectivist philosophical assumption. Both take the position that the world is objectively real, and not simply created in the mind, interpretatively, by each learner (Ertmer \& Newby, 2013).

The perspective that the best approach for understanding the workings of the human mind is objective and scientific measurement of behaviour (rather than the "unscientific" study of consciousness) was first formalized by Watson (1913), and such scientific approaches to psychology developed throughout the first half of the $20^{\text {th }}$ century. From a behaviourist perspective, mind, thoughts, and consciousness are considered to be unobservable phenomena (Akdeniz, 2016; Siemens, 2005). Instead, the focus of behaviourist study is observable behaviour, and the role of environmental factors that influence behaviour (Watson, 1913). For educationalists, behaviourism positions learning as relatively permanent changes in behaviour (Mazur, 2016), and knowledge as something acquired from external sources (Boghossian, 2013; Mazur, 2016). Human beings are imagined to be "blank slates" at birth, and their behaviour subsequently shaped most significantly by their environment, through predictable stimulus/response processes (rather than through mental activities like memory, perception, or thought).

Pedagogical designs founded on behaviourist principles are typically prescriptive, systematic, linear, and focussed on objective goals. Learners are viewed primarily as recipients of knowledge transmitted to them by educators, driving an emphasis on teaching methods (rather than on learning strategies and processes). A perceived benefit of behaviourist design has been ease of assessment, because of its focus on measurable and observable results, which has historically resulted in a heavy focus on quantitative and summative assessment of measurable outcomes.

Later in the $20^{\text {th }}$ century, cognitivism gained attention, offering a perspective on learning in which internal processes of the mind play a more important role (Brown \& Green, 2019). Although cognitivist learning theory also acknowledges reinforcement and environmental factors as motivators (Mergel, 1998), it is less mechanistic in its understanding of the human response to stimuli (Yilmaz, 2011). Instead, cognitive theories highlight the importance of mental processes (perception, thought, 
memory, attention, problem solving, and information processing) in learning, and seek to explain how information processing (receiving, organizing, storing, and retrieving of information) is happening in the mind (Currie, 2004; Ertmer \& Newby, 2013).

Pedagogical designs founded on cognitivist principles typically consider learners be more active participants in the acquisition of knowledge, with learning understood as an active process of receiving, organizing, storing, and retrieving information and knowledge. Educators are less central, and play a guiding role through design and provision of instructional supports such as scaffolding, examples, feedback, and advance organizers for new topics (Mohammadi et al., 2010), and by facilitating recall of prior knowledge (Mergel, 1998) and design of authentic situations for learning.

Instructional design, drawing on behaviourist and/or cognitivist perspectives, developed as a systematic approach to teaching towards achievement learning goals (Reiser \& Dempsey, 2007; Schott \& Seel, 2015; Seel et al., 2017), with learning steps (activities) typically arranged in linear and iterative models (see for example Branch, 2009; Dick et al., 2005; Gagné, 1965; Morrison et al., 2004; Smith \& Ragan, 2004) and assessments designed to measure learner achievement of desired outcomes.

\section{Behaviourist Learning Analytics (BLA)}

At present, the vast majority of learning analytics solutions promoted by educational software vendors, and also the learning analytics features integrated into most learning management systems and other eLearning platforms, are not primarily focussed on how learning is achieved. Instead, they tend to prioritize the collection, analysis, and reporting of data about progression through learning activities, as well as measurement of outcomes of learning (usually grades). Because this heavy focus on measuring the products of learning, and on monitoring progress through learning activities, reflect the core foci of behaviourist/cognitivist approaches to pedagogical design, we refer to this cluster of LA approaches as BLA.

A strength of BLA is its emphasis on observable and quantitatively measurable behaviours and outcomes, making data capture easier. Behaviourist learning analytics tend to collect, analyze and report quantitative metrics (Knight et al., 2013) such as the number of logins and logouts, grades, assignment scores, number of attempts at quizzes, time spent in discussion forums, or number of discussion messages posted by learners. The typically linear and systematic structure of pedagogical designs underpinned by behaviourist (and cognitivist) approaches to instructional design align well with the systematic, pre-set and linear technical processes of many existing learning analytics applications.

Like behaviourist approaches to pedagogical design, BLA applications can also be criticized for being heavily teacher-centric: they typically offer data and insights only to educators, and not to learners themselves. Moreover, and despite the cognitivist interest in mental processes, BLA applications and processes typically give no attention to data that might offer insights into more complex data about learners and learning processes such as cognition, meta-cognition, or higher levels of thinking (e.g., critical and creative thinking). 
Figure 1 offers an example of a classic BLA-oriented dashboard for educators. The developers at the UK Open University describe the goals of their OUAnalyse project as "early identification of students at risk of failing" and "to significantly improve the retention of OU students." They explain that metrics and predictions of failure risk are "available weekly to the course tutors and the Student Support Teams."1

\section{Figure 1}

An Example of BLA: OUAnalyse: An Educator LA Dashboard from the UK Open University
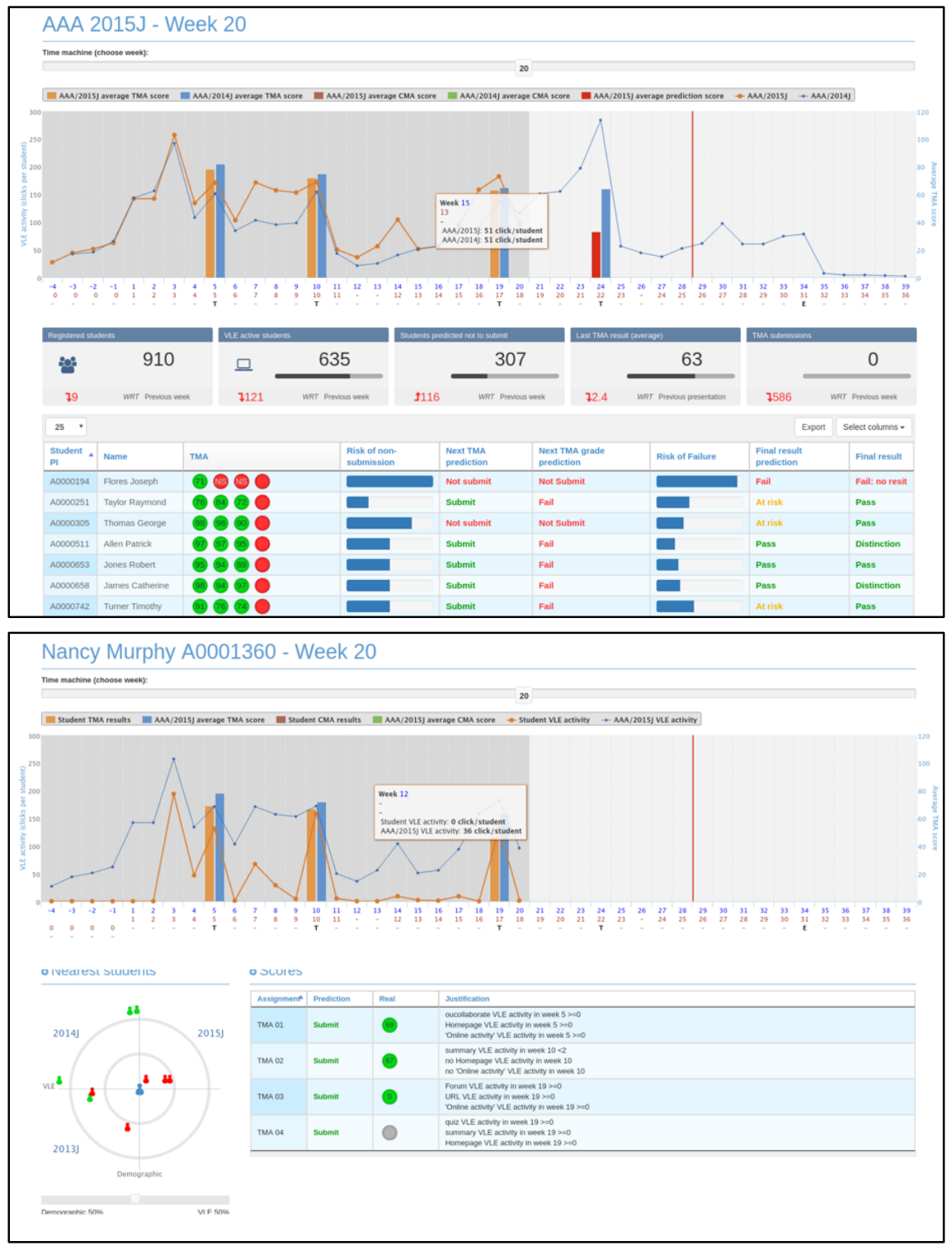

${ }^{1}$ OUAnalyse: https://analyse.kmi.open.ac.uk/ 
It is evident that such an LA solution overwhelmingly collects and displays metrics on progression through a sequence of prepared learning activities and grade achievement in assessments as the primary indicators of learning or "success." Moreover, analytics of this kind offer little insight to educators or instructional designers that could inform effective redesign of a learning environment to optimize learning outcomes. While it is conceivable that future work in educational psychology may offer deeper understanding of the learning processes in behaviourist learning contexts that may direct future selection and analysis of relevant data on learning, we are not aware of learning analytics of this kind at the present time.

\section{Learning Design, Subjectivism, and Constructivist Learning Analytics}

By contrast, the field of learning design, also called learning environment design (LED), has been profoundly shaped by constructivist perspectives on learning (Mor et al., 2015). By the late $20^{\text {th }}$ century, some theorists had begun to question objectivist theories of learning, and instead advanced perspectives, drawing on earlier work by theorists such as Piaget and Vygotsky (Weegar \& Pacis, 2012), that seek to explain how learners construct knowledge (Jonassen, 1991).

Constructivism argues that what people know about the world depends primarily on their own interpretation of their experiences (Ertmer \& Newby, 2013). Learning is therefore understood as a process of personal construction of knowledge from their experiences and building on prior knowledge (Altun \& Büyükduman, 2007; Mergel, 1998; Merrill, 1991; Parker, 2009; Weegar \& Pacis, 2012), rather than acquisition of knowledge transmitted from educators to learners. Social constructivist theories go even further, asserting that collaboration, social interaction, thought sharing, and meaning negotiation offer significant routes to conceptual development and understanding (Altun \& Büyükduman, 2007; Parker, 2009). It is important to note that while cognitivism and constructivism both centre the learner, in the cognitivist view, the learner is a "processor of information," while in the constructivist view the learner not only processes information, but is also responsible for interpreting this information and building personal knowledge (Ertmer \& Newby, 2013). Constructivism is an interpretivist paradigm with a relativist ontology, and a subjectivist epistemology (Levers, 2013). It holds the subjective experiences of the learner to be determining of their individual understanding of reality.

Pedagogical designs rooted in constructivist principles are therefore learner-centred (Gagnon \& Collay, 2005) and consider learners to be responsible for their learning, with educators responsible for designing and facilitating authentic, challenging and problem-based learning activities and environments to effectively achieve learning outcomes (Conole, 2012; Gagnon \& Collay, 2005; Mor \& Craft, 2012). Typically, these evolve as a sequence of learning activities designed to engage learners in interactive and collaborative learning environments (see for example Bybee et al., 2006; Heinich et al., 1999; Jonassen, 1999; Merrill, 2002; Papadakis, 2012). There is an emphasis on subjectivity, and on how something is learned rather than what is learned, with instructional goals and objectives "negotiated rather than set, with no one best way of sequencing instruction" (Cooper, 1993, p. 17). Qualitative approaches to both formative and summative evaluation and assessment are promoted (although assessment remains a challenge in constructivist learning environments). 


\section{Constructivist Learning Analytics (CsLA)}

While instructional design and learning design often embrace similar design structures and a common goal (helping learners achieve the desired learning outcomes), they follow different paths. Learning design focuses mainly on what learners do (Mor et al., 2015; Seel et al., 2017) This perspective is motivated by questions such as: What will be learned? How will it be learned? How will learning be assessed? (Ifenthaler et al., 2018).

Berland et al. (2014) propose that learning analytics can help constructivist educators provide a rich learning environment for learners. With the learner at the heart of the pedagogical process (Gagnon \& Collay, 2005), and the learning process given greater importance than learning outcomes, we have classified as constructivist learning analytics (ConLA) those LA tools and approaches that focus on capturing, analyzing, and reporting data that can provide insights into learning process (Knight et al., 2014). Data that answer questions about how learning is progressing, and the degree to which learners are engaging in desired learning behaviours, are more important than quantitative and summative performance metrics (Altun \& Büyükduman, 2007; Merrill, 1991). Moreover, since formative assessment is a feature of constructivist learning design (Jonassen, 1991), CsLA trace data about learning activities rather than teaching activities, and typically give feedback to learners as well as educators about how they are learning. Since constructivist approaches to education focus (in principle, at least) on learning context, social communications, meta-cognition and higher levels of thinking, constructivist learning analytics concentrate on collecting, analyzing, and reporting more complex and qualitative data.

Social network analysis (SNA) offers one of the better-known approaches to analyzing and visualizing learning processes documented in the LA literature (see for example Dawson, 2009). Network metrics (centrality measures) generated by SNA offer deeper insights into evolving learning networks, by illuminating, for example, which learners are the most active, which learners are the most connected, and which learners may be brokering information flow between sub-groups (Buckingham et al., 2011). Arguably, SNA can illuminate the degree to which a learning design is facilitating the desired social constructivist learner activity. Increasingly, developers are building plug-ins and tools that allow easy network analysis of online learning network communications (Figure 2), and which can reveal network participation to learners as well as educators. 


\section{Figure 2}

Learning Network Visualization of Learner Communications in an Online Course Discussion, Visualized with the Threadz ${ }^{2}$ Plugin for the Canvas LMS

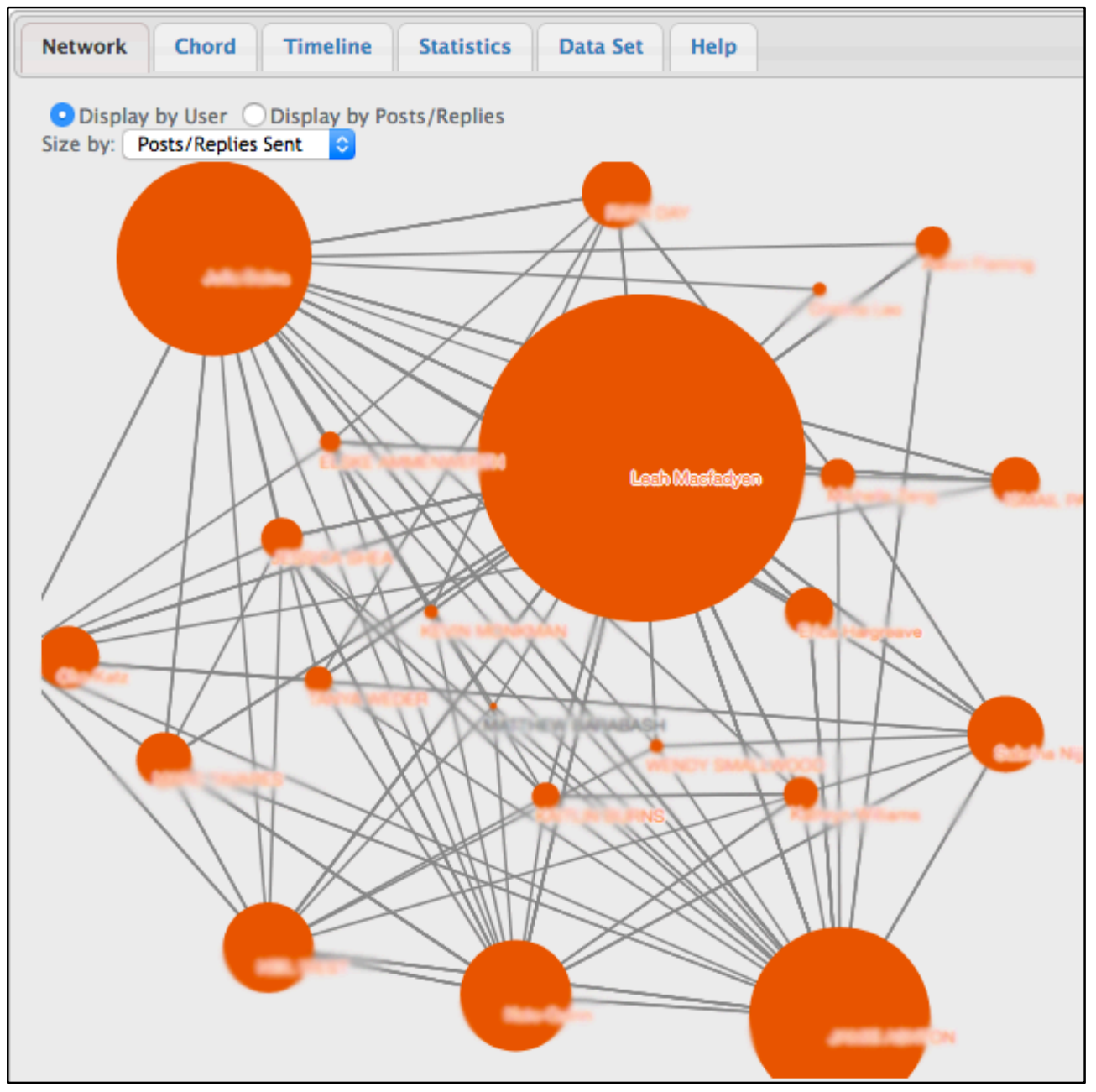

In a different area of work, a range of text mining and natural language processing methods are being employed to assess relevance, quality or evolving complexity, and sophistication or rhetorical structure of learner work compiled in ePortfolios or submitted over time (McNamara et al., 2017). Figure 3, for example, offers a screenshot of the AcaWriter tool ${ }^{3}$, recently developed and piloted at the University of Technology, Sydney. Explicitly developed as learner-facing tool, AcaWriter natural language processing (NLP) software identifies features of a learner's writing such as key concepts, people, and places, and the degree to which the learner is learning to make scholarly knowledge claims.

\footnotetext{
${ }^{2}$ Threadz: https://threadz.ewu.edu/

${ }^{3}$ AcaWriter: https://acawriter.uts.edu.au/
} 
It offers learners automated feedback to help them develop their academic and reflective writing (Shibani et al., 2019).

The sometimes nonlinear and often qualitative and interpretive nature of constructivist learning designs are often seen as a challenge in relation to data collection. A recent review gives grounds for optimism, however, reporting that in recent years LA research has begun to move away from predictive modelling, and towards a deeper understanding of learning experiences (Viberg et al., 2018).

\section{Figure 3}

NLP-generated Writing Feedback Generated by AcaWriter

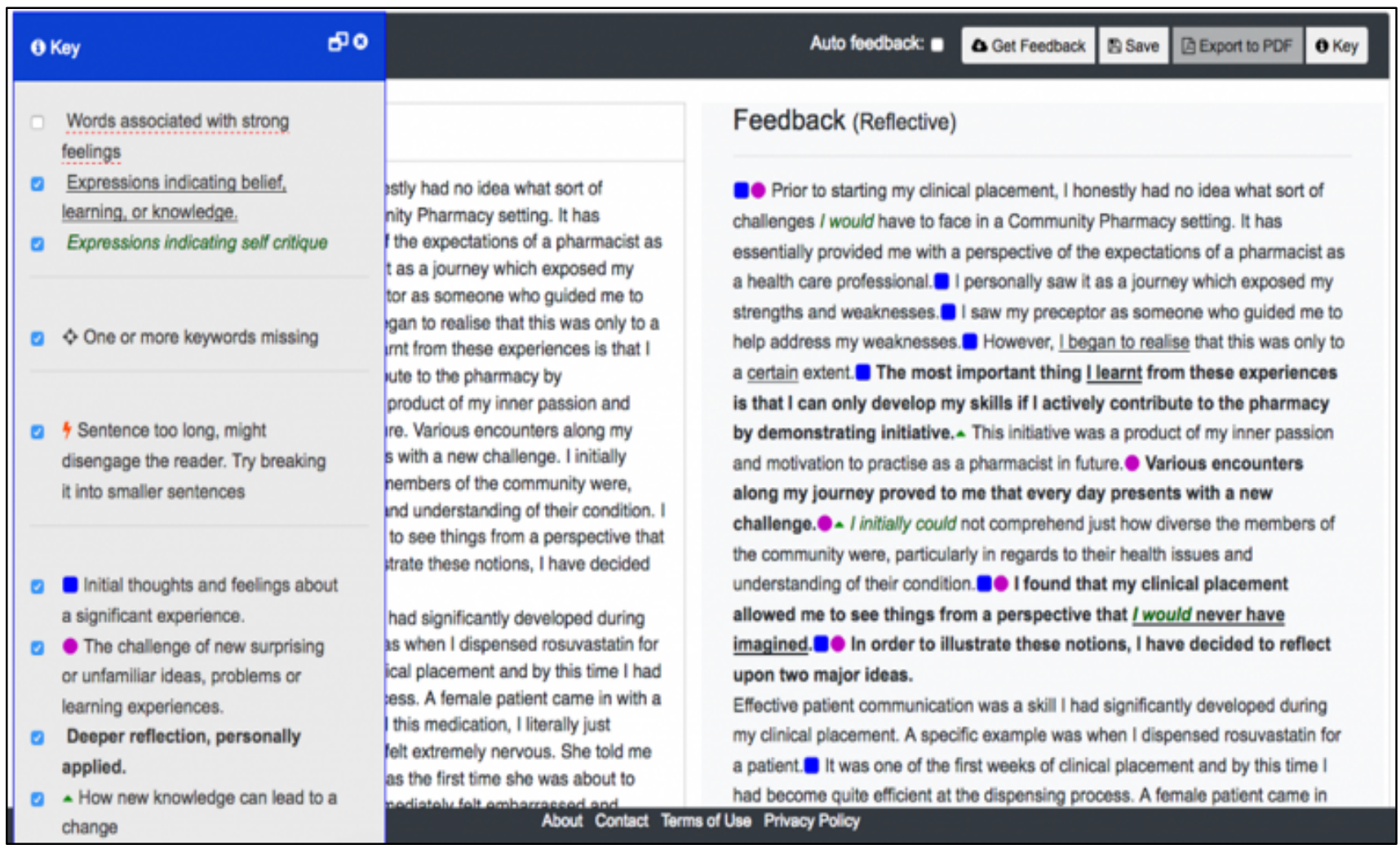

\section{Learning Ecosystem Design, Connectivism, and Connectivist Learning Analytics}

Siemens (2005) has argued that traditional learning theories, such as those described above, fail to meet the learning needs of the digital age. Such theories, he contends, are limited in their capacity to accommodate interpersonal perspectives on learning, are unable to address the learning that is located within and supported by technology and organizations, and give no insight into the processes of value judgement that are needed for learning in knowledge-rich environments (Bell, 2009; Siemens, 2005). Instead, Siemens has elaborated a connectivist learning theory, epistemologically grounded in the notion of connective knowledge (also called distributed knowledge) (Downes, 2008), which he argues is more relevant to learning needs in the current era - one in which technology shapes our lives, an explosion of knowledge is occurring, and rapid evaluation of knowledge is important. Connectivism offers an approach to accommodating in our design and pedagogy the new understandings of chaos, 
complexity, and networks that have been driven by the technology explosion (Dunaway, 2011; Siemens, 2005).

As outlined by Siemens (2005), connectivism asserts that:

- Learning and knowledge rest in diversity of opinions.

- Learning is a process of connecting specialized nodes (also called entities) or information sources into networks.

- Learning may reside in non-human appliances.

- Capacity to know more is more critical than what is currently known.

- Nurturing and maintenance of connections is needed to facilitate continual learning.

- Ability to see connections between fields, ideas, and concepts is a core skill.

- Currency (accurate, up-to-date knowledge) is the intent of all connectivist learning activities.

- Decision-making is itself a learning process. (p. 7)

In contrast with theories that view knowledge as constructed internally by individuals, or collaboratively through social negotiation, connectivist theory posits that knowledge is "distributed across a network of connections, and therefore that learning consists of the ability to continuously construct and traverse those networks" (Downes, 2008; Duke et al., 2013). Learning is understood to take place when learners make connections with other nodes (individuals, ideas, organizations, websites, journals, computers, etc.) (Dunaway, 2011; Siemens, 2005). Rapid evaluation of knowledge, and more importantly, preservation of the capacity to learn more, is therefore more important than what is learned now.

Connectivism holds some specific educational implications for educators and learners. Learning is viewed as a process of creating and navigating networks, with pedagogical design focused on facilitating interaction, information flow, and networked learning. Gathering and distributing diverse and current knowledge (Kizito, 2016; Siemens, 2005; Siemens \& Tittenberger, 2009) from networks are understood to be intrinsic features of learning, and the learning environment is viewed as an ecosystem - virtually a living organism.

Design for learning and knowledge in connectivist-inspired learning contexts remains learnercentred but requires facilitating the creation of current and dynamic knowledge-sharing networks. Learners are viewed as nodes in an ecosystem of interconnected networks (Banihashem \& Aliabadi, 2017) and they make use of the ecosystem to build their own personal connections and networks (Richardson, 2002). Such learning ecosystems are envisioned as rich, dynamic, and fluid environments that facilitate complex interactions, connections, and flow of information and knowledge, and have the capacity to grow, self-organize and constantly evolve (Pradhan, 2016, February 19; Richardson, 2002). They are open, dynamic, independent, and adaptive systems that include both interpersonal interactions 
and interactions with non-human components such as technologies and organizations (Brown, 2000; Gütl \& Chang, 2008; Saadatmand, 2017).

While the concept of a learning ecosystem aligns well with our understanding of the chaotic, rapidly growing and connected nature of knowledge in the current era, it is nonetheless challenging to design a learning environment which is pedagogically well-matched with evolving and complex nature of connectivism (Bell, 2011; Kop \& Hill, 2008). Some have suggested that the LEDs implied by connectivist learning theory are thus far poorly understood (see for example Chatti, 2010).

\section{Connectivist Learning Analytics (ConLA)}

In principle, connectivist learning analytics should be heavily geared towards analyzing how well a learner is creating networks, how the learner is communicating with other learners, and how effectively information and knowledge are flowing in a learning network. Siemens (2008) has argued that connectivist learning analytics may be best suited for understanding complex learning processes in contexts of rapid change and diverse knowledge sources, and should focus on collecting data about nodes, networks, and their inter-relationships.

Methodologically, social network analysis offers some analytic potential for connectivist learning ecosystems, but a challenge is the risk of over-valuing (or over-interpreting) simple network membership or participation, and of overlooking the complexity of fine-grained network activity (Knight et al., 2014). To provide meaningful connectivist learning analytics, analysis must go beyond straightforward reporting of "who is connected with whom" and must also seek to integrate data on "who is connected with what" (such as ideas, devices, publications, or organizations). Analysis of information flow, diversity, dynamism, and knowledge currency all seem pertinent in a connectivist learning ecosystem, as well as interaction within learning networks, though examples are few.

Rosé et al. (2015) and Crosslin et al. (2018) describe an experimental effort to design an explicitly connectivist multi-level MOOC, which integrated multiple and optional innovative forms of support for discussion-based learning, social learning, and self-regulated learning. These authors outline their technical efforts to integrate learner contributions from multiple channels, but to date, and perhaps reflecting the significant pedagogical challenge of connectivist learning environment design (Bell, 2011; Kop \& Hill, 2008), no vision for meaningful ConLA to support learners or educators in that context has emerged.

One potential analytic approach that may valuably contribute to connectivist LA is epistemic network analysis (ENA). As Shaffer et al. (2016) explain, ENA "is a set of techniques that identifies and measures connections among elements in coded data and represents them in dynamic network models" (pp. 9-10). They highlight that ENA allows modelling of network change over time including changes in composition and strength of connections - and allows comparison of networks, "so that it can be used to explore a wide range of qualitative and quantitative research questions in situations where patterns of association in data are hypothesized to be meaningful" (p. 10). Shaffer and Ruis (2017) offer a worked example of ENA applied to educational data from a learning environment 
to illustrate the potential of this approach. Development of meaningful connectivist learning analytics associated with effective connectivist learning ecosystems nevertheless remains an open challenge.

\section{Where Learning Theory and Learning Analytics Meet}

Above, we have sought to illuminate the connections between underlying learning theory (beliefs about what constitutes learning), choice of design approach for learning, and the LA tools or methods that are most likely to offer insights into the desired learning. Learning analytics are, first and foremost, about learning (Gašević et al., 2015). If learning analytics seeks to understand and optimize learning in a selected learning environment, then it is vital to acknowledge how learning is believed to take place in that environment, how we believe our design strategy is supporting learning (Wong et al., 2019), and what kinds of data will meaningfully offer insight into the learning of individuals.

Pragmatically, pedagogical design (shaped by learning theory and underlying epistemology) offers guidance as to how learning analytics might best be used to support that design and the learning goals it specifies. If we have espoused a constructivist learning design underpinned by a commitment to social negotiation of meaning, for example, then a behaviourist LA application designed to monitor task completion will be unlikely to offer meaningful understanding of how our learning design is influencing learning or learner achievement. Effective and successful application of learning analytics in educational contexts demands that we give attention to the theoretical foundations of the learning contexts we design (Gašević et al., 2016; Gašević et al., 2015; Knight et al., 2013; Koh et al., 2016; Stewart, 2017; Wise, 2014).

In Figure 4, we build on earlier work by Knight et al. (2014) and summarize schematically the three categories of learning analytics proposed in this paper, separated conceptually at the level of relevance to learning theory. While these categories may each make use of some of the same underlying data (for example, learner demographic data, performance data, or learning process data), each is employed for very different pedagogical and interpretive purposes, supporting the assertion by Gašević et al. (2016) and others that "one size" of learning analytics definitively cannot meet the needs of all pedagogical design frameworks. The role of theory in learning analytics application, then, is that it gives different meaning to data (Wong et al., 2019).

Furthermore, failure to consider theoretical foundations risks allowing learning analytics to drive the pedagogical bus, generating data on and measuring outcomes for activities that are not relevant in the pedagogical design. Technological and mechanical determinism, resulting from the poorly thought-out application of convenient, promoted or available learning analytics tools, is a real danger (Knight et al., 2014; Siemens et al., 2013). We cannot and must not design learning environments and learning outcomes to fit available learning analytics tools. 


\section{Figure 4}

Conceptual Framework of Different Learning Analytics Approaches

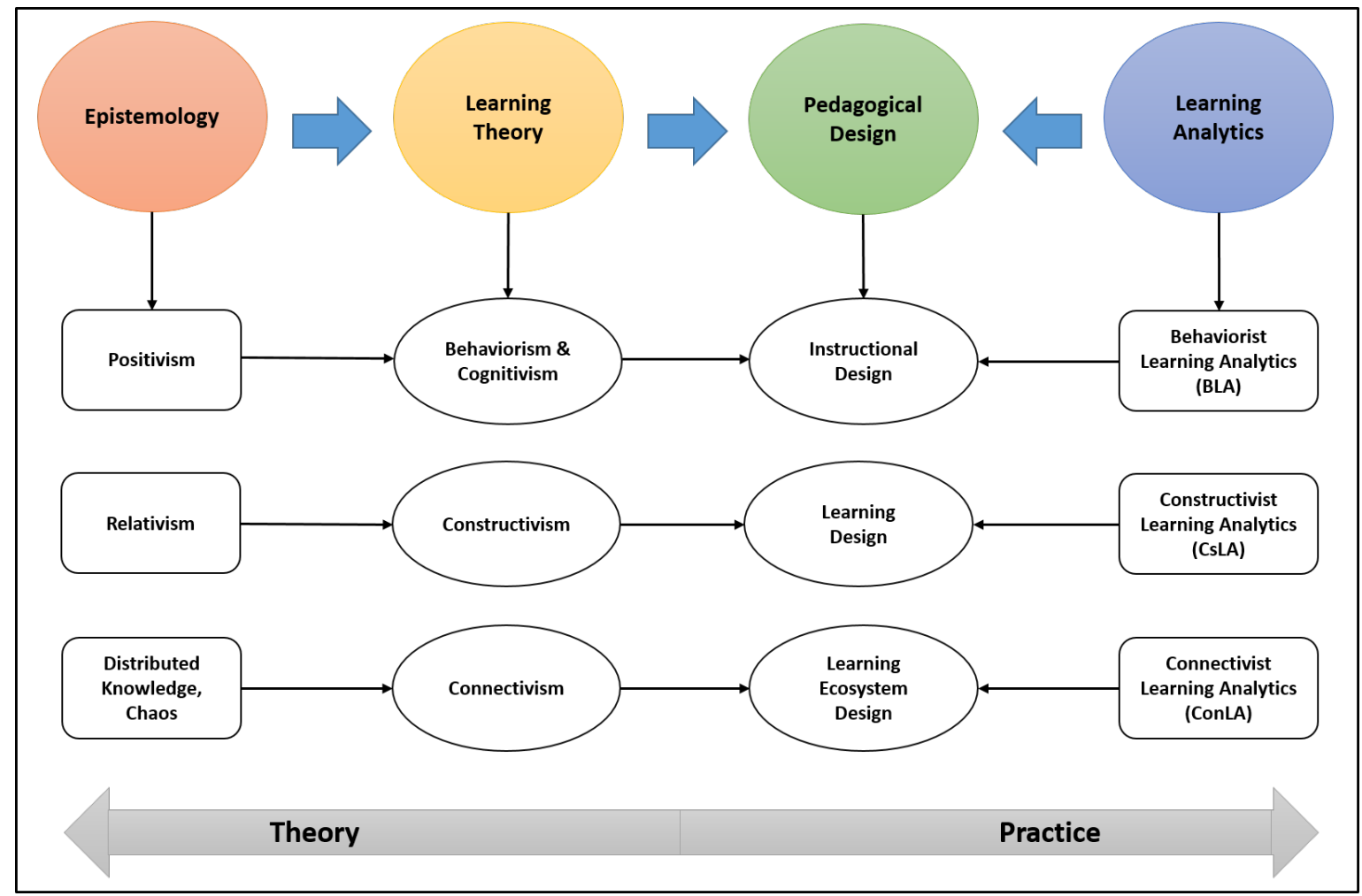

Wise predicted in 2014 that LA would not meaningfully influence teaching and learning until it was designed into the larger pattern of instruction, but to date most LA literature continues to address researchers, and not pedagogical designers, practitioners or educators (Ferguson \& Clow, 2017; Viberg et al., 2018). These same authors highlight the slow pace of meaningful LA implementation in educational contexts, and the resultant lack of evidence of impact of LA in authentic settings. The pragmatic next step calls for embedding and testing relevant learning analytics approaches in different and appropriate pedagogical designs. It is our hope that ongoing theoretical and empirical work investigating the interconnections between learning analytics, learning theory, and learning design will engage educators and pedagogical designers as collaborators in this work, and assist with selection of the best possible learning analytic approaches to support and illuminate learning outcomes of their pedagogical projects.

\section{Author Note}

Correspondence concerning this article should be addressed to Leah P. Macfadyen, Associate Director, Master of Educational Technology Program, UBC Faculty of Education, 305D-2125 Main Mall, Vancouver, BC, V6T 1Z4, Canada. Email: leah.macfadyen@ubc.ca 


\section{References}

Akdeniz, C. (Ed.) (2016). Instructional process and concepts in theory and practice. Improving the teaching process. Springer Science.

Altun, S., \& Büyükduman, F. I. (2007). Teacher and student beliefs on constructivist instructional design: A case study. Kuram ve Uygulamada Egitim Bilimleri, 7(1), 30-39.

Banihashem, S. K., \& Aliabadi, K. (2017). Connectivism: Implications for distance education. Interdisciplinary Journal of Virtual Learning in Medical Sciences, 8(3). http://dx.doi.org/10.5812/IJVLMS.10030

Banihashem S. K., Aliabadi K., Pourroostaei Ardakani S., Delavar, A., \& Nili Ahmadabadi, M. R. (2018). Learning analytics: A systematic literature review. Interdisciplinary Journal of Virtual Learning in Medical Sciences, 9(2). https://dx.doi.org/10.5812/ijvlms.63024

Banihashem, S. K., Aliabadi, K., Pourroostaei Ardakani, S., Nili AhmadAbadi, M. R., \& Delavar, A. (2019). Investigation on the role of learning theory in learning analytics. Interdisciplinary Journal of Virtual Learning in Medical Sciences, 10(4), 14-27.

http://dx.doi.org/10.30476/IJVLMS.2019.84294.1001

Barron, A. B., Hebets, E. A., Cleland, T. A., Fitzpatrick, C. L., Hauber, M. E., \& Stevens, J. R. (2015). Embracing multiple definitions of learning. Trends in Neurosciences, 38(7), 405-407. https://dx.doi.org/10.1016/j.tins.2015.04.008

Bell, F. (2009). Connectivism: A network theory for teaching and learning in a connected world. Educational Developments, The Magazine of the Staff and Educational Development Association, 10(3). http://usir.salford.ac.uk/id/eprint/2569/

Bell, F. (2011). Connectivism: Its place in theory-informed research and innovation in technologyenabled learning. The International Review of Research in Open and Distributed Learning, 12(3), 98. https://dx.doi.org/10.19173/irrodl.v12i3.902

Berland, M., Baker, R. S., \& Blikstein, P. (2014). Educational data mining and learning analytics: Applications to constructionist research. Technology, Knowledge and Learning, 19(1-2), 205220. https://doi.org/10.1007/s10758-014-9223-7

Boghossian, P. (2013). Behaviorism, constructivism, and Socratic pedagogy. Educational Philosophy and Theory, 38(6), 713-722. https://doi.org/10.1111/j.1469-5812.2006.00226.x

Branch, R. M. (2009). Instructional design: The ADDIE approach. Springer Science \& Business Media.

Brown, A. H., \& Green, T. D. (2019). The essentials of instructional design: Connecting fundamental principles with process and practice. Routledge.

Brown, J. S. (2000). Growing up digital: How the web changes work, education, and the ways people learn. USDLA journal, 16(2), n2. https://doi.org/10.1080/00091380009601719 
Buckingham Shum, S., \& Ferguson, R. (2011). Social learning analytics. The Open University, UK: Knowledge Media Institute. http://kmi.open.ac.uk/publications/pdf/kmi-11-01.pdf

Bybee, R. W., Taylor, J. A., Gardner, A., Van Scotter, P., Powell, J. C., Westbrook, A., \& Landes, N. (2006). The BSCS 5E instructional model: Origins and effectiveness. BSCS. https://bscs.org/resources/reports/the-bscs-5e-instructional-model-origins-and-effectiveness/

Chatti, M. A. (2010). The LaaN theory. In Personalization in technology enhanced learning: A social software perspective (pp. 19-42). Shaker Verlag. http://mohamedaminechatti.blogspot.com/2013/01/the-laan-theory.html

Chen, P.-S. D., Lambert, A. D., \& Guidry, K. R. (2010). Engaging online learners: The impact of webbased learning technology on college student engagement. Computers \& Education, 54(4), 1222-1232. https://doi.org/10.1080/13562517.2013.827653

Clow, D. (2013). An overview of learning analytics. Teaching in Higher Education, 18(6), 683-695. https://doi.org/10.1080/13562517.2013.827653

Conole, G. (2012). Designing for learning in an open world. New York, USA: Springer Science \& Business Media.

Cooper, P. A. (1993). Paradigm shifts in designed instruction: From behaviorism to cognitivism to constructivism. Educational Technology, 33(5), 12-19. https://www.jstor.org/stable/44428049

Crosslin, M., Dellinger, J. T., Joksimovic, S., Kovanovic, V., \& Gaševic, D. (2018). Customizable modalities for individualized learning: Examining patterns of engagement in dual-layer MOOCs. Online Learning, 22(1), 19-38. http://dx.doi.org/10.24059/olj.v22i1.1080

Currie, G. (2004). Cognitivism. In T. Miller \& R. Stam (Eds.), A companion to film theory (pp. 105122). John Wiley \& Sons.

Dawson, S. (2009). 'Seeing' the learning community: An exploration of the development of a resource for monitoring online student networking. British Journal of Educational Technology, 41(5), 736-752. http://dx.doi.org/10.1111/j.1467-8535.2009.00970.x

Dick, W., Carey, L., \& Carey, J. O. (2005). The systematic design of instruction. Pearson/Allyn and Bacon.

Downes, S. (2008). An introduction to connective knowledge. Media, Knowledge \& Education: Exploring new Spaces, Relations and Dynamics in Digital Media Ecologies (pp. 77-102). Innsbruck University Press. https://www.oapen.org/search?identifier=449459

Duke, B., Harper, G., \& Johnston, M. (2013). Connectivism as a digital age learning theory? The International HETL Review, 2013(Special Issue), 4-13. https://www.hetl.org/wpcontent/uploads/2013/09/HETLReview2013SpecialIssueArticle1.pdf

Dunaway, M. K. (2011). Connectivism: Learning theory and pedagogical practice for networked information landscapes. Reference Services Review, 39(4), 675-685. https://doi.org/10.1108/00907321111186686 
Ertmer, P. A., \& Newby, T. J. (2013). Behaviorism, cognitivism, constructivism: Comparing critical features from an instructional design perspective. Performance Improvement Quarterly, 26(2), 43-71. https://dx.doi.org/10.1002/piq.21143

Ferguson, R., \& Clow, D. (2017). Where is the evidence? A call to action for learning analytics. Seventh International Conference on Learning Analytics \& Knowledge (pp. 56-65). ACM. https://doi.org/10.1145/3027385.3027396

Gagné, R. M. (1965). Conditions of learning. Holt McDougal.

Gagnon, G. W., \& Collay, M. (2005). Constructivist learning design: Key questions for teaching to standards. Corwin Press.

Gašević, D., Dawson, S., Rogers, T., \& Gasevic, D. (2016). Learning analytics should not promote one size fits all: The effects of instructional conditions in predicting academic success. The Internet and Higher Education, 28, 68-84. https://doi.org/10.1016/j.iheduc.2015.10.002

Gašević, D., Dawson, S., \& Siemens, G. (2015). Let's not forget: Learning analytics are about learning. TechTrends, 59(1), 64-71. https://dx.doi.org/10.1007/s11528-014-0822-x

Gütl, C., \& Chang, V. (2008). Ecosystem-based theoretical models for learning in environments of the 21st century. International Journal of Emerging Technologies in Learning (iJET), 3(2008). http://dx.doi.org/10.3991/ijet.v3i1.742

Halttunen, K. (2011). Pedagogical design and evaluation of interactive information retrieval learning environment. In E. Efthimiadis, J. Fernández-Luna, J. Huete, \& A. MacFarlane (Eds.), Teaching and learning in information retrieval (pp. 61-73). Springer.

Heinich, R., Molenda, M., Russell, J., \& Smaldino, S. (1999). Instructional media and technologies for learning (6th ed.). Prentice Hall.

Ifenthaler, D., Gibson, D., \& Dobozy, E. (2018). Informing learning design through analytics: Applying network graph analysis. Australasian Journal of Educational Technology, 34(2). https://doi.org/10.14742/ajet.3767

Jonassen, D. H. (1991). Objectivism versus constructivism: Do we need a new philosophical paradigm? Educational Technology Research and Development, 39(3), 5-14. https://doi.org/10.1007/BF02296434

Jonassen, D. H. (1999). Designing constructivist learning environments. In C. M. Reigeluth (Ed.), Instructional-design theories and models: A new paradigm of instructional theory (pp. 215239). Lawrence Erlbaum Associates.

Kizito, R. N. (2016). Connectivism in learning activity design: Implications for pedagogically-based technology adoption in African higher education contexts. International Review of Research in Open and Distributed Learning, 17(2), 19-39. https://doi.org/10.19173/irrodl.v17i2.2217 
Knight, S., Buckingham Shum, S., \& Littleton, K. (2013). Epistemology, pedagogy, assessment and learning analytics. Proceedings, Third International Conference on Learning Analytics and Knowledge (pp. 75-84). ACM. https://doi.org/10.1145/2460296.2460312

Knight, S., Shum, S. B., \& Littleton, K. (2014). Epistemology, assessment, pedagogy: Where learning meets analytics in the middle space. Journal of Learning Analytics, 1(2), 23- 47. https://doi.org/10.18608/jla.2014.12.3

Koh, E., Shibani, A., Tan, J. P.-L., \& Hong, H. (2016). A pedagogical framework for learning analytics in collaborative inquiry tasks: An example from a teamwork competency awareness program. Proceedings, Sixth International Conference on Learning Analytics \& Knowledge (pp. 74-83). ACM. https://doi.org/10.1145/2883851.2883914

Kop, R., \& Hill, A. (2008). Connectivism: Learning theory of the future or vestige of the past? The International Review of Research in Open and Distributed Learning, 9(3). https://doi.org/10.19173/irrodl.v9i3.523

Levers, M.-J. D. (2013). Philosophical paradigms, grounded theory, and perspectives on emergence. SAGE Open, 3(4), 1-6. https://doi.org/10.1177/2158244013517243

Long, P., \& Siemens, G. (2011). Penetrating the fog: Analytics in learning and education. EDUCAUSE Review, 45(6). Retrieved from https://er.educause.edu/articles/2011/9/penetrating-the-foganalytics-in-learning-and-education

Mazur, J. E. (2016). Learning and behavior (8th ed.). Routledge.

McNamara, D. S., Allen, L., Crossley, S., Dascalu, M., \& Perret, C. A. (2017). Natural language processing and learning analytics. In C. Lang, G. Siemens, A. Wise, \& D. Gašević (Eds.), Handbook of learning analytics (1st ed., pp. 93-104). Society for Learning Analytics Research (SoLAR). https://doi.org/10.18608/hla17.008

Mergel, B. (1998). Instructional design and learning theory. http://citeseerx.ist.psu.edu/viewdoc/download?doi=10.1.1.645.7122\&rep=rep1\&type=pdf

Merrill, M. D. (1991). Constructivism and instructional design. Educational Technology, 31(5), 45-53. https://www.jstor.org/stable/44427520

Merrill, M. D. (2002). First principles of instruction. Educational Technology Research and Development, 50(3), 43-59. https://doi.org/10.1007/BF02505024

Mohammadi, M., Moenikia, M., \& Zahed-Babelan, A. (2010). The role of advance organizer on English language learning as a second language. Procedia-Social and Behavioral Sciences, 2(2), 4667-4671. https://doi.org/10.1016/j.sbspro.2010.03.747

Mor, Y., \& Craft, B. (2012). Learning design: Reflections upon the current landscape. Research in Learning Technology, 20, 85-94. https://doi.org/10.3402/rlt.v20i0.19196 
Mor, Y., Craft, B., \& Maina, M. (2015). Introduction: Learning design: Definitions, current issues and grand challenges. In Y. Mor, B. Craft, \& M. Maina (Eds.), The art \& science of learning design (pp. ix-Xxvi). Sense.

Morrison, G. R., Ross, S. J., \& Kemp, J. E. (2004). Designing effective instruction (4th ed.). John Wiley \& Sons.

Papadakis, S. (2012). Enabling creative blended learning for adults through learning design. In P. S. Anastasiades (Ed.), Blended learning environments for adults: Evaluations and frameworks (pp. 257-273). IGI Global.

Parker, K. H. (2009). Constructivist learning design: A qualitative study of learning theory and at-rsk student academic success. [Doctoral dissertation, Capella University]. Available from ProQuest Dissertations and Theses database (3355349). https://www.proquest.com/openview/acfa703c696a3e9a9148a5f8a0262016/1?pqorigsite $=$ gscholar $\& \mathrm{cbl}=18750$

Perelmutter, B., McGregor, K. K., \& Gordon, K. R. (2017). Assistive technology interventions for adolescents and adults with learning disabilities: An evidence-based systematic review and meta-analysis. Computers \& Education, 114, 139-163. https://doi.org/10.1016/j.compedu.2017.06.005

Pradhan, A. (2016, February 19). 6 steps to creating learning ecosystems (why you should bother). https://learnnovators.com/blog/6-steps-to-creating-learning-ecosystems-and-why-you-shouldbother/.

Prasertsilp, P. (2013). Mobile learning: designing a socio-technical model to empower learning in higher education. LUX: A Journal of Transdisciplinary Writing and Research from Claremont Graduate University, 2(1), 23. https://scholarship.claremont.edu/lux/vol2/iss1/23/

Reiser, R. A., \& Dempsey, J. V. (2007). Trends and issues in instructional design and technology. Allyn \& Bacon.

Richardson, A. (2002). An ecology of learning and the role of elearning in the learning environment. Global Summit of Online Knowledge Networks, (pp. 47-51). Education.au Limited.

Romiszowski, A. J. (2016). Designing instructional systems: Decision making in course planning and curriculum design. Routledge.

Rosé, C. P., Ferschke, O., Tomar, G., Yang, D., Howley, I., Aleven, V., . . . Baker, R. (2015). Challenges and opportunities of dual-layer MOOCs: Reflections from an edX deployment study. 11th International Conference on Computer Supported Collaborative Learning (CSCL 2015) (pp. 848-851). International Society of the Learning Sciences, Inc. https://84.38.64.180/data/publications/2015/RoseCSCL2015.pdf 
Saadatmand, M. (2017). A new ecology for learning: An online ethnographic study of learners' participation and experience in connectivist MOOCs. [Doctoral dissertation, University of Helsinki]. http://urn.fi/URN:ISBN:978-951-51-3191-1

Sawyer, R. (2014). Introduction: The new science of learning. In R. Sawyer (Ed.), The Cambridge handbook of the learning sciences (Cambridge Handbooks in Psychology, pp. 1-18). Cambridge University Press. https://doi.org/10.1017/CBO9781139519526.002

Schott, F., \& Seel, N. M. (2015). Instructional design. In International encyclopedia of the social \& behavioral sciences (2nd ed., pp. 196-200). Elsevier. https://doi.org/10.1016/B978-0-08097086-8.92032-4

Seel, N. M., Lehmann, T., Blumschein, P., \& Podolskiy, O. A. (2017). Instructional design for learning: Theoretical foundations. Sense.

Shaffer, D. W., Collier, W., \& Ruis, A. R. (2016). A tutorial on epistemic network analysis: Analyzing the structure of connections in cognitive, social, and interaction data. Journal of Learning Analytics, 3(3), 9-45. https://doi.org/10.18608/jla.2016.33.3

Shaffer, D. W., \& Ruis, A. (2017). Epistemic network analysis: A worked example of theory-based learning analytics. In C. Lang, G. Siemens, A. F. Wise, \& D. Gaševic (Eds.), The Handbook of Learning Analytics (1st ed., pp. 175-187). Society for Learning Analytics Research (SoLAR). https://doi.org/10.18608/jla.2016.33.3

Shibani, A., Knight, S., \& Shum, S. B. (2019). Contextualizable learning analytics design: A generic model and writing analytics evaluations. Proceedings of the Ninth International Conference on Learning Analytics \& Knowledge (pp. 210-219). ACM. https://doi.org/10.1145/3303772.3303785

Siemens, G. (2005). Connectivism: A learning theory for the digital age. International Journal of Instructional Technology and Distance Learning, 2(1), 3-10. https://www.itdl.org/Journal/Jan_05/Jan_05.pdf

Siemens, G. (2008). Learning and knowing in networks: Changing roles for educators and designers. ITFORUM for Discussion, 27, 1-26.

Siemens, G., Dawson, S., \& Lynch, G. (2013). Improving the quality and productivity of the higher education sector. Policy and strategy for systems-level deployment of learning analytics. Society for Learning Analytics Research \& Australian Government Office for Learning and Teaching. https://solaresearch.org/wp-content/uploads/2017/06/SoLAR_Report_2014.pdf

Siemens, G., \& Tittenberger, P. (2009). Handbook of emerging technologies for learning. University of Manitoba.

Smith, M. (1999-2020). Learning theory. In M. Smith (Ed.), The encyclopedia of pedagogy and informal education. https://infed.org/mobi/learning-theory-models-product-and-process/

Smith, P. L., \& Ragan, T. J. (2004). Instructional design. John Wiley \& Sons. 
Stauter, D. W., Prehn, J., Peters, M., Jeffries, L. M., Sylvester, L., Wang, H., \& Dionne, C. (2019). Assistive technology for literacy in students with physical disabilities: A systematic review. Journal of Special Education Technology, 34(4), 284-292. https://doi.org/10.1177/0162643419868259

Stewart, C. (2017). Learning analytics: Shifting from theory to practice. Journal on Empowering Teaching Excellence, 1(1), 10. https://doi.org/10.15142/T3G63W

Viberg, O., Hatakka, M., Bälter, O., \& Mavroudi, A. (2018). The current landscape of learning analytics in higher education. Computers in Human Behavior, 89, 98-110. https://doi.org/10.1016/j.chb.2018.07.027

Watson, J. B. (1913). Psychology as the behaviorist views it. Psychological Review, $20(2), 158$. https://doi.org/10.1037/h0074428

Weegar, M. A., \& Pacis, D. (2012). A comparison of two theories of learning-behaviorism and constructivism as applied to face-to-face and online learning. Paper presented at the CASA eleader conference, Manila, 2012. https://g-casa.com/conferences/manila/papers/Weegar.pdf

Wise, A. (2014). Designing pedagogical interventions to support student use of learning analytics. Proceedings, Fourth International Conference on Learning Analytics \& Knowledge (pp. 203211). ACM. https://doi.org/10.1145/2567574.2567588

Wong, J., Baars, M., de Koning, B. B., van der Zee, T., Davis, D., Khalil, M., . . Paas, F. (2019). Educational theories and learning analytics: From data to knowledge. The whole is greater than the sum of its parts. In D. Ifenthaler, D. K. Mah, \& J. K. Yau (Eds.), Utilizing learning analytics to support study success (pp. 3-25). Springer. http://dx.doi.org/10.1007/978-3-319-64792-0_1

Yilmaz, K. (2011). The cognitive perspective on learning: Its theoretical underpinnings and implications for classroom practices. The Clearing House: A Journal of Educational Strategies, Issues and Ideas, 84(5), 204-212. https://doi.org/10.1080/00098655.2011.568989 


\section{Authors}

Seyyed Kazem Banihashem holds a doctorate in the field of educational technology from Allameh Tabataba'i University, Iran. He is currently a postdoctoral researcher at Wageningen University and Research, in the Netherlands. His research interests include learning analytics, learning theories, learning design, and feedback.

Leah P. Macfadyen is Assistant Professor of Teaching in the Department of Language and Literacy Education, and Associate Director of the Master of Educational Technology Program, in the Faculty of Education of the University of British Columbia in Vancouver, Canada. Her research interests include virtual intercultural communication, eLearning design, and learning analytics. Email: 